\title{
Defending the North: Frontline Cairns (1940-1946) - an historical overview \\ Timothy Bottoms
}

\section{Introduction}

The defence of Australia during the Second World War in the Pacific lay in the north of the continent: from Broome and Darwin to Cairns and Townsville. After the Japanese military swept through South East Asia, they were at Australia's backdoor. Initially, there was a quiet period where little appeared to be happening. Then a rapid build-up of Allied military strength began. Cairns, the closest city to the conflict; was only $1000 \mathrm{kms}$ from Port Moresby and Papua New Guinea, and the war that raged in the Coral Sea and Melanesia. The hostilities were closer to the people of Cairns than their State capital, Brisbane, $1800 \mathrm{kms}$ to the south. Roads, bridges, airfields and port facilities had to be greatly improved. All this and trying to keep Allied soldiers from quarrelling - the scene was set for the transformation of the sleepy tropical township of Cairns, where sugar, tourism and fishing held sway, to a busy centre converting to a forward base for the defence of the nation.

\section{The Coming of War to FNQ}

In mid-1941, six months before the Japanese attacked Malaya and Pearl Harbor, the 'Cairns to Kuranda' Range road was opened for traffic. ${ }_{1}$ It was to be one of the most vital links in the joint Australian and American defence of the Far North.

Following the September 1939 announcement of war with Germany, a 'Northern Centres Alert' was issued for defensive preparations in Townsville and Cairns. In the north they were more advanced than in other Queensland centres: The Cairns Harbour Board (2 September 1939) closed its wharves to the public and instituted a permit system, while'Militia guards had been placed over the oil depots and other vital northern points $s_{2} \ldots$ All bridges on the main arterial roads in North Queensland were under armed guard; and patrols had been stationed at most power houses and water reticulation areas.' $\underline{3}$

There was also urgent need to upgrade Cairns aerodrome. An immense amount of work was required to make it militarily operational, particularly during the Wet Season. By December 
1941 the Federal government had approved and begun to develop Advanced Operational Bases for the RAAF at Cairns (as well as Cooktown, Coen, Horn Island, and Mackay). 4

In late July 1941, the sobering news was received of Japanese troops landing in southern Indo-China. Some five months later, like so many others, eleven-year-old Bill Mehlert, gathered with his family around the wireless:

At about $8 \mathrm{pm}$ we listened to Prime Minister Curtin's declaration of war with Japan. $\underline{\underline{5}}$ I don't think Mum slept at all that night...[U]ntil December 1941 the war seemed remote to most of us and to many Australians, myself included, the Pacific War became THE war. Monday, 8 December 1941, $\underline{6}$ became the central focus for us. The unthinkable had actually happened full-scale war on our northern doorstep. ${ }_{\underline{7}}$

The increasing Japanese successes led to blackout conditions being introduced in early December 1941. Radio stations (including 4CA in Cairns) had to cease broadcasting at night in order to deprive enemy aircraft of direction-finding opportunities. ${ }_{8}$ Air-raid shelters were built in the business district and slit trenches were dug in school grounds and house yards. 9 Those of the boating fraternity who had their rowboats on the beach or moored removed them and stored them at home. ${ }_{10}$ The ground crews for an advance base for the Catalina flyingboats began arriving and setting up $\mathrm{p}_{11}$ and the minesweeper HMAS Bungaree laid minefields in the waters off Port Moresby and passageways through the Great Barrier Reef. 12

With the Japanese advancing down the Malay Peninsula heading for Singapore, locals heard of the capture of the Australian base at Rabaul, New Britain. ${ }_{13}$ Several hundred Australian troops were killed. ${ }_{14} \mathrm{By}$ early February, Port Moresby was being bombed, then Singapore fell (15 February), and four days later Darwin was bombed and Timor invaded. 15 Then the crushing defeats in the Battles of Java Sea and Sunda Strait followed. $\underline{16}$ Prime Minister Curtin perceived the fall of Singapore as 'Australia's Dunkirk' and that this heralded the battle for Australia. ${ }_{17}$ However, what really seems to have galvanised the resolve of everyday Australians was the attack on Darwin. It was felt that somehow 'Australian soil was sacred, unique, inviolable. The reality of war in our own country jolted us like nothing else.' ${ }_{18}^{18}$ One Gordonvale resident recalled that there was "not a soul in the street. If you turned the corner you put your head round to see if there were any Japanese uniforms there. That's how we felt. We expected them any day." $\underline{19}$ The arrival of the damaged hospital ship Manunda and several other ships, from Darwin, brought home the truth. One waterfront worker remembered the 
cargo boat Barossa was 'still smouldering when she arrived in Cairns. The bridge section was burnt out and emergency equipment had to be installed for steering and navigation...' $\underline{20}$ Compounding this were a variety of vessels fleeing with expatriates from the Japanese advance in New Guinea and the islands of the South Pacific. Some 2,000 civilians by air and several thousand by 'diverse' ships made their way to the North Queensland coast. 21 Empire flying boats of the RAAF No.11 Squadron, were re-assigned to evacuate civilians from Port Moresby, Rabaul, $\underline{22}$ Lae and other locations in New Guinea and the Islands (including the Torres Strait and Cape York Peninsula) back to mainland Australia.

The litany of disasters continued with Japanese troops invading Java (1 March), $\underline{23}$ and Rangoon (8 March), and occupied Lae and Salamaua in New Guinea. Nevertheless, an adolescent at the time recalled, 'there was no atmosphere of giving up or surrender. Everybody I knew - children, men, women, grandfathers and grandmothers - all were going to fight regardless of the odds.' $\underline{24}$ Some sense of relief was gained when some of the first units from the AIF in the Middle East, began to arrive back to defend Australia. $\underline{25}$ Then U.S. General Douglas MacArthur, having fled the Philippines, arrived in Australia mid-March, and by late July 1942 had moved his headquarters from Melbourne to Brisbane. ${ }_{26}$ Morale, as historian Geoffrey Bolton observed, 'remained good, even at the height of the Japanese threat when between five and seven thousand evacuees were removed from Cairns, $\underline{27}$ a like number from Townsville.' $\underline{28}$

\section{Evacuation \& Internment ${ }_{29}$}

In late January 1942, nearly a thousand women and children were evacuated by train to the

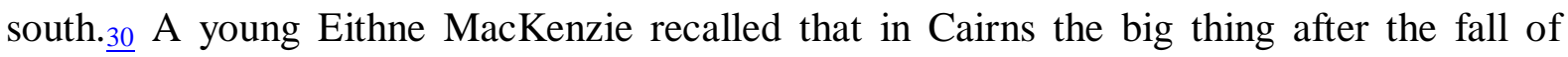
Singapore (15 February) was evacuation:

The women and children left almost overnight. They went to the Tablelands and Charters Towers. Where we lived there were very few women left in the block. There might have been three houses that had people in. The rest were all empty. Homes and furniture were sold at ridiculous prices. There were great auction sales. ${ }_{31}$ A lot of people who bought were the auctioneers and agents. After the war they sold and made great profits. Other people left. They just walked out. $\underline{32}$ 
Following the Pearl Harbor attack in December 1941, $\underline{\underline{33}}$ all Japanese in Australia were taken into custody, $\underline{34}$ including those who lived and worked in the Cairns district. ${ }_{\underline{35}}$ The fear that Japanese were gathering intelligence and geographical information was the basis of the official response. $\underline{36}$ Between September and December 1939, only 1\% (or 70) of Queenslands' 7,000 residents of German descent were interned. $\underline{37}$ However, for Cairns and district, it was Italy's declaration of war following Japan's surprise attacks, which began a renewed phase of Australia's internment policy. $\underline{38}_{\underline{3}}$ February 1942 saw the first train-load of internees leave from the North and by September, 6,780 Italian-Australians were interned. $\underline{39}$ Those not interned found their position became increasingly difficult with regulations restricting their movements, which also involved reporting weekly to the local police station, $\underline{40}$ and with the cessation of naturalisation, migrants classed as 'Enemy Aliens' were not allowed to lease or purchase land. $\underline{11}$

Some petty local jealousies appear to have been behind disputes over land. $\underline{42}$ Inaccurate informing of police about Italian farmers and cane-cutters' activities, was also compounded by the fervent support of the forerunner of the RSL. $\underline{3}$ From 1939-45, Queensland, at 43\%, had the highest internment rate in the nation. The internments left families without their menfolk. 44 It was a shameful episode in Australia's history. ${ }_{45}$ It also did more harm than was necessary as a contributing factor in the sugar industry slump during the war.

\section{4. 'The Lull Before the Storm' - Cairns, 1942}

Not surprisingly, Cairns had become a lonely outpost, with the loss of $78 \%$ of the child population of Cairns, amongst the 5-7,000 residents evacuated $\underline{47}$ from a 1941 population of 15,700. ${ }_{48}$ Meanwhile the word had passed around the district that the Americans were looking for female parachute packers at Gordonvale. The procedure of selection led to only 17 women being accepted. The paratroopers did not arrive until December. 49

Newspapers 'nearly every day published advertisements announcing the closure of some once prosperous business. About half the shops in the main business area of Cairns became vacant, and rents for city establishments collapsed...' $\underline{50}$

Residents of Cairns and district were still feeling particularly vulnerable. Unbeknownst to them, ${ }_{51}$ in early February 1942 , the commanding officer of the $51^{\text {st }}$ Battalion met with local government authorities and their engineers, as well as representatives from the oil companies, 
in order to plan the destruction of essential services and infrastructure should the Japanese invade. $\underline{52}$ However, after three weeks of working secretly, the $51^{\text {st }}$ Battalion was sent to defend Townsville. Feeling unprotected, the local authorities sent representatives to Canberra to lobby for sending help to the far North. $\underline{53}$

No doubt the requisitioning of 300 tractors and other farm machinery from North Queensland farmers, to help construct bridges, roads, airfields, accommodation for troops and civilian workers during mid-1942, $\underline{54}$ also added to feelings of insecurity. This, along with the shortage of labour and fertilizer led to a slump in sugar production. $\underline{55}$

State's rights and a perception that the Commonwealth had neglected Queensland and the North $_{\underline{56}}$ along with the interlude prior to the military build-up, increased North Queensland's acceptance of the myth of the 'Brisbane Line'. Although staged withdrawal was apart of official policy, no documentary confirmation has been found to corroborate the existence of the 'Brisbane Line'. $\underline{57}$ Nevertheless, it added to Northerners' sense of grievance. $\underline{58}$

The first troops of any numbers to arrive were the $17^{\text {th }}$ Australian Field Engineer Company, in late April 1942, who buoyed the spirits of a beleaguered Cairns. The $17^{\text {th }}$ were the 'demolition boys', who completed the job begun by the $51^{\text {st }}$ in case of invasion and mined the Kuranda Range Road and other main transport links such as the Gillies Highway, $\underline{59}$ the Bump Track, railway and wharf facilities. On the Atherton Tableland it took workers only eight days during March/April to build a new Mareeba airfield capable of taking United States Air Force B-17 Flying Fortresses. $\underline{60}$ Later in the year there were nearly 10,000 Americans in and around Mareeba, which had a local population of 2,500. One year later, the Americans had gone. $\underline{61}$

For seven days, from Monday 4 May 1942, the Battle of the Coral Sea raged some 1200 kilometres off the North Queensland coast. 'Cairnsites' were, as Vera Bradley recalled: 'aware that an important battle was being fought not far from our shores and everyone was apprehensive about the outcome. When the news seeped out that the Japanese mission had been thwarted, a new wave of optimism swept throughout the north.' ${ }_{62}$ It was the first major aircraft carrier confrontation in World War Two, and was the first time in naval history that opposing surface ships did not sight one another. ${ }_{63} \mathrm{~A}$ month later the Battle of Midway ${ }_{\underline{64}}$ began (3 June 1942) and by 6 June, the Japanese had suffered their worst naval defeat in their history. 
Nonetheless, the threat to Australia was still seen as being very real, particularly when the Japanese landed (21 July) at Gona and Buna on the north eastern side of Papua; the northern end of the Kokoda Trail. $\underline{65}$ The small Australian force of 400 men was driven back until September at Imita Ridge, $\underline{66}$ when a counter-offensive was begun. $\underline{67}$ The Australian $7^{\text {th }}$ Division drove the over-stretched and fever-ridden remnants of the Japanese XVII Army back, $\underline{68}$ taking Kokoda and control of the Owen Stanley Range. By late January 1943, with the loss of 2,000 Australians killed, the Japanese had been driven back at Sanananda with a loss of 13,000 soldiers. $\underline{69}$

\section{Frontline Cairns $\underline{70}$}

In April 1942, Cairns was still within range of long-distance Japanese bombers. 71 In October, RAAF No. 20 Squadron moved to Cairns. They were located in a row of huts built for them along the Esplanade. Some 3,000 sorties were flown from Cairns, but not all returned. 320 Australian airmen who flew Catalinas in the South-West Pacific theatre of war never came back. $\underline{72}$

In early August, United States forces landed on the islands of Tulagi and Guadalcanal in the Solomon Islands and a vicious six-month struggle followed. ${ }_{73}$ Several weeks later (on 25 August, 1942) the Japanese landed at Milne Bay on the eastern tip of Papua $\underline{74}$ although they were forced to evacuate 13 days later. ${ }^{75}$ In early December Australians re-captured Gona. The tide of war was turning and with it the fortunes of the Cairns district.

Communications infrastructure was particularly limited in North Queensland with Cape York being served by one single galvanised wire which could only cope with 50 telegrams an hour. ${ }_{76}$ During 1942 the military authorities, in conjunction with the Post Master General's (PMG's) office, used U.S. Army signals corps troops, Australian Army Signalmen, and PMG linesmen to improve the communication links. Wharf facilities improved, and large storage oil-tanks for the Royal Australian Navy (RAN) were constructed $5 \mathrm{kms}$ from the wharves at Edge Hill.

The influx of thousands of Australian servicemen and women to the North, as well as Americans, British and some Dutch and their Indonesian allies had resulted in almost every building in Cairns being occupied by military units. $\underline{78}$ A business boom rapidly followed and agricultural production sky-rocketed, with some farmers and businessmen clearing their long- 
standing overdrafts 'almost overnight' ${ }^{79}$ However, there was also a growing shortage of farm workers. Aboriginal labour from Yarrabah and Monamona Missions, $\underline{80}$ as well as the Australian Women's Land Army, ${ }_{11}$ went to work. The Queensland government acknowledged that Aboriginal labour was 'instrumental in harvesting crops [on the Atherton Tableland] which were considered essential to Primary Industry,' $\underline{22}$ and to the war effort.

There had been some American military presence in Cairns since November 1941, but it was not until December 1942, that some 3,500 men of the US 503 ${ }^{\text {rd }}$ Parachute Infantry Regiment arrived. ${ }_{83}$ No camp or mess facilities had been established for them but their Commanding Officer $_{84}$ had visited Gordonvale and asked help in preparing food for the Regiment's arrival late that afternoon. ${ }_{85}$ Local residents, including members of the CWA and bakers, rallied to the cause. One American paratrooper, recalled:

carloads of ladies and men came along carrying what seemed to be an unlimited amount of food. They made salad rolls and gave us cakes, watermelon, oranges and cups of (hot) tea, which we were not used to, but we were so hungry we would have consumed anything. This generous effort endeared them to us, especially when they welcomed us into their homes. .86

They left for Port Moresby in August 1943.

Christmas Day 1942 saw the arrival of a unit of the Royal Australian Artillery. two searchlights at Sunny Bay, $\underline{89}$ while the Civil Construction Corps undertook the construction of the False Cape gun emplacements. At this stage there wasn't a road to Bessie Point or Second Beach. $\underline{90}$ The Shire loaned a punt for the project. By early December 1943, two $155 \mathrm{~mm}$ guns and two searchlights were placed in their permanent position. A week later, the signallers arrived and set up. Their main functions were to provide a line of communications to ships, relaying information and monitoring ship movements. $\underline{91}$

Early 1943 saw the American military arriving in force. 22 Major infrastructure changes for the district began with the arrival of the US 411 Engineer Base Shop Battalion (EBS). 93 By necessity, road improvements and bridge building had to be implemented, although, as one of the US Navy members from New Jersey, recalled: 'Our purpose for being there was to give the Aussie AIF $9^{\text {th }}$ Division training in amphibious boat and shore landings. These exercises were carried out at Trinity and Palm beaches using landing barges built in Cairns.' ${ }_{94}$ More than 1,000 were put together at this Cairns Australian plant before it was moved to Milne 
Bay. 25 The massive increase in activity on the northern Beaches led to another problem of the tropical coast came into focus: marine stingers. $\underline{96}$

During 1942-43, 18 ships were sunk off the eastern Australian seaboard with a total loss of 468 lives. 97

In July 1942, the 'Z' \& 'M' Special Units of the Allied Intelligence Bureau were sent to Cairns, and set-up their headquarters at 'Fairview', or what became known as 'The House on the Hill'. It now became 'out-of-bounds' to civilians as the men trained for what turned out to be 260 wartime missions behind enemy lines. $\underline{\text { g }}$ A new wireless shed was constructed to contact Allied Intelligence overseas. In May 1943, ZES force became 'M' Force (or 'M' Special Unit 'Raiding') operating under Australian command.

It was from Cairns that the former Japanese fishing boat, renamed the Krait by the Australian Navy (RAN), set forth, first to Exmouth on the northern coast of Western Australia and then to successfully raid Singapore Harbour (27 September 1943). The ZES force caused a great deal of damage, sinking or disabling seven ships, and causing nearly 40,000 tons of shipping damage. $\underline{99}$

One member of this elite and secretive force, Allan Amos, remembered how

We were always on the alert that the local population might find out what we were doing. They were continually told to report any suspicious actions in their areas. To test their diligence, and as an exercise on survival while remaining undetected, I drove five or six of the Indonesian boys out behind Redlynch. They failed on all four exercises, as the people of Redlynch and Freshwater Valley reported them each time. $\underline{100}$

In 1944, the 'House on the Hill' was handed over to the Dutch and Indonesian Intelligence Services. Their exploits, while veiled in secrecy, did manage to ignite contact stories with the local Aboriginal missions. Certainly, members of Monamona Mission saw men hiding in trees by their shadows on the ground, across the river from Oak Forest. They were not white men, and fitted an Aboriginal perception of Japanese, and so the alarm went out...'the Japanese are coming!' Upon investigation by the local policeman it was discovered they were Javanese not Japanese, which suggests that they were part of the Netherlands East Indies Intelligence training at 'Fairview' $\cdot \underline{101}$ 
By December 1942 the Australian Army had devised a regular system of rotation of troops between North Queensland and Papua.102 Mid-1943 there were heavy troop movements operating through the Redlynch Army Staging Camp either making their way to the jungletraining and/or recuperation camps on the Tableland or preparing to embark for overseas service. 103 On occasions there were between 50,000 and 100,000 troops quartered on the Atherton-Evelyn Tablelands, 104 with an average constant of roughly 40,000 troops. 105 The Australian $9^{\text {th }}$ Division shipped off to land and capture Lae (4-16 September). Later in the year the Americans landed in the Gilbert Islands and New Britain. ${ }_{106}$ As Paul Wilson observed: 'the role of North Queensland slowly changed from that of a forward operational area to that of a replacement, repair, reinforcement and retraining base. Until the War moved away from New Guinea in 1944-45, North Queensland was the most important Allied base in the South West Pacific area.' 107

\section{Public Health During the War}

On the frontline, malaria was destroying the effective strength of troops in New Guinea (for both the Japanese and the Allies) $)_{108}$ and posed a most critical threat. ${ }_{109}$ It was readily apparent that whoever won the battle over fevers and malaria had a distinct advantage in winning the war. Nearly $45 \%$ of Australian troops in Port Moresby were infected with malaria. 110 Medical concern $_{111}$ proved to be well founded when a serious malarial epidemic almost immobilised the Milne Bay force in November and December 1942. 112

A general policy began of sending all service patients and returning troops who had contracted malaria in New Guinea to the Atherton Tableland. Cairns became the focal point of an epic undertaking in planning and implementing malaria-research in Australia. It became the training ground for Malaria Control Units, before they were transferred to New Guinea or the islands. In a co-operative venture between local, state and federal authorities, and the Australian and U.S. Armies, 26 miles $(42 \mathrm{kms})$ of anti-malarial drains were constructed in Cairns.

Between 1942 and 1945 some 2,000 civilians and military personnel contracted malaria in the district, $\underline{114}$ but by 1948 the number of people suffering from malaria had dropped to nil. $\underline{115}$ 


\section{Women at War}

The shortage of labour was to increase the role women were to play in implementing total war. 116 Almost 50,000 women were serving by early 1944 and many were working skilled jobs previously the preserve of men. Voluntary self-sacrifice was promoted by the federal

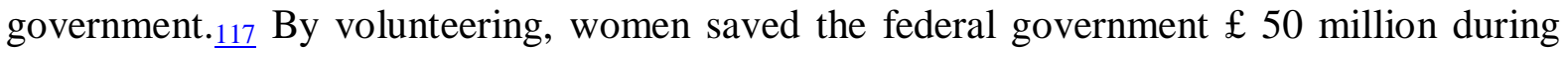
the war. Australia-wide the numbers of women in the paid work-force jumped by $33 \% . \underline{118}$

The numbers of armed service personnel were to build to half a million over the next 18 months, peaking at wars' end with 863,000 . As Bolton says, 'it was the first time in the history of white Australia that such a concentration of foreigners had entered the country.' 119 Although in North Queensland, there had always been a polyglot of peoples.

With the war on the doorstep, socialising helped morale, and Australian women were discovering the gentlemanly behaviour of the visiting American servicemen, who were not only well paid and tailored, but also had access to goods Australians had not seen for ages. $\underline{120}$

\section{War-time Cairns}

Queensland rail traffic during the war jumped by $66 \%$ and had the highest density of rail traffic in Australia. Similarly in Cairns, traffic greatly increased. Extensions to the main railway lines on the Tableland enabled troops and supplies to access their training camps. $\underline{121}$ The Cairns-Kuranda section was so busy at one stage that in one 24-hour period, a record 43 trains chugged up the range. 122

Work output fell as the Japanese retreated and strikes and absenteeism increased. Bolton notes that 'Such stoppages exasperated the middle class and the Americans, and embarrassed the Curtin government, divided as it was between its Labor loyalties and commitment to winning the war.' $\underline{123}$ The Australian waterfront had reached a chaotic stage in early 1942. Pillaging from wharves had risen by $36 \%$ over 15 months. This situation resulted in the creation of the Stevedoring Industry Commission. Shipping historian, Norman McKellar identified: 'the beginning of the end of the old system of waterside employment'. Waterfront strikes in Cairns throughout the war infuriated Australian troops fighting in New Guinea. Army radio telegraphist, Harry Speight, was stationed at Milne Bay and learned from transmissions about the 'wharfies' going on strike. He remembered: 
they would not load any artillery, motor or aerial bombs unless they were paid DANGER MONEY. They claimed it was too hazardous. What about us, all we had left was our rifles and bayonets, knee deep in mud with mozzies eating us and the Japs knocking at our door, and they said it was too dangerous!! $\underline{125}$

The largest strike to occur at the port of Cairns during the war was in April/May 1945, when some 800 men from the Australian $6^{\text {th }}$ Division (AIF) were hurriedly sent from Kairi on the Tableland to the city wharves. Speight remembered: 'We were told that an Army detachment was sent to load the ship and instructed to 'shoot the bastards if they didn't leave within 30 seconds'.'126 A member of this Emergency Corps, Max Herron recalled 'each company worked a full 12-hour shift, being relieved by another crew for the remaining 12 hours of loading. They all faced the same risks for a paltry six bob a day, a wage far less than that paid to the waterside workers.' 127 Australian troops thus had their ammunition and supplies when they landed at Balikpapan, Borneo in July 1945.

\section{Riots and Redlights}

Initially, conflict between Allied military forces in Australia were minimal. However, this 'honeymoon' period was ended by an American serviceman when he committed several murders in Melbourne in May 1942, $\underline{128}$ after which there was an escalation of confrontations between Australians and Americans. 129 Within the American services there was a high degree of violence, $\underline{130}_{2}$ which was mostly racially based. ${ }_{131}$ US Forces operated on segregated lines. Australian authorities upheld the policies of 'White Australia'. ${ }_{132}$ While the Queensland Government's oppressive control and segregation of Aborigines, kept African American servicemen restricted to segregated locations and confined to inferior and separate recreational facilities. $\underline{133}$

The first major confrontation erupted into what became termed the 'Battle of Brisbane' inlate November 1942, 134 followed in December by another riot in Fortitude Valley. Cairns and the far North were not immune either. Eighteen year-old Commonwealth Bank clerk, Peter Merrotsy remembered one riot in September 1943:

As machine guns blazed Mrs Darley, the manager's wife, called from the verandah above us, 'Boys, boys, remember your mothers.' Unfortunately, the boys were not interested at that moment in their mothers, their only thought was to finish the fight which had erupted the 
night before at the Trocodero dance hall where Aussies who had just returned from the Middle East were indignant to find our girls dancing with the Yanks and they threw everyone of them down the steps onto the street. $\underline{135}$

Then the Provosts (Military Police) arrived and naturally a confrontation resulted. The Australians were confined to barracks and future leave arrangements allowed for alternate days for the respective armies.

The brothels of Cairns' old Chinatown area still operated, but this time with queues. $\underline{136}$ Although prostitution was still illegal in Queensland, officials turned a blind eye, except ostensibly for the more obvious establishments.

One early September Friday evening in 1944, an impatient 'Aussie' soldier tried to enter the American Red Cross Service Club in Spence Street.137 A US Shore Patrol guard, using the typical American military response, hit the Australian with his baton, which caused even the Australian Provosts to object. From this, a major brawl erupted, with, as Military Policeman Ian Cox, recalled:

Word of the fight spread like wildfire and truck-loads of AIF and US troops training out at the beaches were brought into the fray. Quite a nasty situation developed which took hours for the military authorities of both sides to bring under control. $\underline{138}$

Navy man, Clive Wise was at the pictures when the fighting began and after the film, they were collected by the Navy Shore Patrol and ushered back to base at HMAS Kuranda. Wise was issued a pick handle:

and placed on duty near the main entrance, directly opposite the American Red Cross. I can assure you I was scared stiff watching the Yanks driving around with .05 machine-guns mounted on their jeeps and packing 45 s on their hips. There I stood with the pick handle. I suppose the general idea was that I was to use it like a cricket bat and hit the bullets back at the Yanks. $\underline{139}$

All military units were confined to base.

At 8.44 am on Wednesday 15 August in 1945, the Allied code-word 'Neon', was flashed around the world and by 9.30 am, Ben Chifley, the Australian Prime Minister was 
broadcasting on the wireless to the nation, the news: the war was over!Cairns went delirious with joy in celebrating victory in the Pacific; for the rest of the morning an impromptu procession of gaily bedecked vehicles with flags and exuberant people made many rounds of the main streets. 140

\section{Reflection}

The war-years of 1940-45 had been particularly turbulent for Cairns and district, especially in contrast with the more populated southern states. The impact of the war in the region was profound, marking a major transition period in twentieth century history. In Cairns and surrounds the changes could most obviously be seen in the improved infrastructure developments: sealed Gillies and Kuranda Range roads, rail extensions, wharf facilities, an extensive malarial drainage system, not to mention the extension and sealing of many roads on the Tableland. The Cairns Harbour Board for example gained by nearly $£ 1$ million improvements effected by the US Navy. 141

During the war especially in North Queensland, Australians had been exposed to the habits and mores of a large number of people from around the world, which broadened their perspectives. $\underline{142}$

The separation of 4 to 6 years, quite often put a strain on marriages, and as Vera Bradley observed, 'often the person who went away and the one left behind were entirely different people at the end of it all.' $\underline{143}$

Twenty year old Dorothy Duffy, who had spent her youth growing up on the wartime Tableland, knew that the madness and chaos of wartime conditions had been real enough but felt, as a result, that she was much, much, older than her age. Duffy encapsulated the impact of so many troops on the districts' residents with her comments:

the ever-changing movement of troops around us, some becoming friends to remain so for life, some merely touching the surface of life, now only a faint memory or a name in an autograph book. The desperate need to hold on to the present in case there wasn't going to be a future, and the deep and intense feelings unequalled in peace-time. $\underline{144}$ 
Having experienced this fear, the future could only look golden, and Cairns re-embraced the quiet pre-war life of tourism, sugar and fishing, although with a greater awareness of a world that had quickly lost interest in them.

\section{Notes}

1 H.A.Borland, Roadway of Many Memories 1876 - 1951, Worker Newspaper Pty Ltd., Brisbane, 1951, p.29. "Late in 1937 a P.E.I. - Public Estate Improvement - road was under construction from Kuranda to MacKenzie's Pocket, which was on the desired Kuranda road route only three miles [4.8 kms] from the Cook Highway...following closely the alignment of the old Government dray route." Jones, Trinity Phoenix, 1976, p.473. G. Pike, 'Introduction' in E.S.W. May, The Kuranda Range Road, E.S.W. May, Atherton, 1996, p.5 \&.22.

2 These were the Voluntary Defence Corps (VDC), aged between 17 and 65. See V. Bradley, I didn't know that, Boolarong Press, Moorooka, 1995, pp.31-33.

${ }_{3}$ Sunday Australian [Cairns], 9 September 1945, p.1. See also G.L. Broughton, "A Short History of Cairns During the War Years", Historical Society of Cairns (HSC), Bulletin 257, April 1981.

${ }_{4}$ Royal Australian Air Force. P.D. Wilson, North Queensland WWII 1942-1945, Department of Geographic Information, Brisbane, 1988, p.18.

${ }_{5}$ John Joseph Curtin (ALP) became Prime Minister of Australia on 7 October 1941. He was to lead Australia through the trials and tribulations of the war years, and on "5 July 1945, with victory in the Pacific just six weeks away, he died, to almost universal dismay." D. Day, "John Joseph Curtin", in M. Grattan (ed), Australian Prime Ministers, New Holland, Sydney, 2000, p.237.

${ }_{6}$ Curtin, instead of the passive acceptance of war as in 1939, made a formal declaration in a national broadcast on Monday evening, 8 December 1941, where he stated "Men and women of Australia. We are at war with Japan. That has happened because, in the first instance, Japanese naval and air forces launched an unprovoked attack on British and United States 
territory; because our vital interests are imperilled, and because the rights of a free people in the whole Pacific are assailed." G. Souter, Acts of Parliament - A narrative history of Australia's Federal Legislature, MUP, Carlton, 1989, p.344. See also J. Beaumont, (ed) Australia's WAR 1939-40, Allen\& Unwin, St. Leonards, 1996, pp.27-28.

${ }_{7}$ A[lbert].W[illiam]. Mehlert, "Looking Back: Looking Ahead 1942-1992", HSC, Bulletin 379, May 1991, p.2. Nineteen days later the Prime Minister acknowledged that "Australia looks to America, free of any pangs as to our traditional ties of kinship with the United Kingdom. We know the problems that the United Kingdom faces. We know the constant threat of invasion, we know the dangers of dispersal of strength, but we know, too, that Australia can go and Britain can still hold on." Melbourne Herald, 27 December, 1941, quoted in Beaumont, op.cit., p.31.

${ }_{8}$ P.D. Wilson, North Queensland WWII 1942-1945, Department of Geographic Information, Brisbane, 1988, map.

${ }_{9}$ Cairns Post, 10 December 1941.

10 Or the military in the form of the $17^{\text {th }}$ Australian Field Engineers Company(RAE), of the AIF would lend an involuntary hand. V. Bradley, I didn't know that, Boolarong Press, Moorooka, 1995, p.56; G.L. Broughton, "A Short History of Cairns During the War Years", HSC, Bulletin 257, April 1981.

11 W.T. Johnston, "Vignettes of Cairns During the Pacific War years", HSC, Bulletin 261, August 1981.

12 It was during August, October and November 1941 that the mine-sweeper's northern work was implemented in "the waters of Port Moresby, One and a Half Mile Opening and Cooks Passage north of Cooktown and near the opening into Trinity Passage." Bradley, op.cit., 1995, p.159.

13 The Japanese invasion force comprised some 25 ships (men-of-war, transports, minesweepers, tankers and air-craft carrier) and launched their attack on Rabaul, on 19 January 1942. They had aerial superiority (at 20 to 1), and quickly destroyed four of the five Wirraways, whose crews ( 2 each, 10 in total), knew their aircraft were no match for the Japanese fighters. Despite this they exhausted their ammunition, and "With silenced guns, 
one of the Australians plunged across the sky at a fighter which still poured lead at him. Straight at the black shape of the enemy he flew, and crashed into him, plunging with him to the sea below." Sunday Australian [Cairns], 9 September 1945, p.13.

14 On 23 January 1942. Beaumont, op.cit., p.27. The Australian defenders laid down a withering fire on the Japanese landing barges. One of the AIF defenders, Alf Price recalled that the Japanese attackers, "sold their lives dearly; so dearly that it is estimated that more than 2000 Japanese dead (Alf Price says 3000) were left to rot on the beaches of Rabaul before the last living Australian fled to the jungle to carry on the fight, or escape, as the circumstances indicated." Price led 18 men to safety, by escaping into the jungle and leading the party to the coast and rescue by three enterprising civilians ['Cook and Keogh were miners; Shaw had been a Government officer.'] who in their schooner, 'moving by night, hiding by day, risking death every hour', they made their way across the Coral Sea and safety at Mourilyan Harbour. Sunday Australian [Cairns], 9 September 1945, pp.13-14.

15 19-20 February 1942 .

$\underline{16} 27$ February - 1 March 1942, and HMAS Perth was sunk.

17 Beaumont, op.cit., p.30.

$\underline{18}$ Bill Mehlert, op.cit.

19 Interview with Dr J. Brody, Cairns Oral History Project (COHP), Tape 0397, 1A, 12 December 1997.

${ }_{20}$ G.L. Broughton, "A Short History of Cairns During the War Years", HSC, Bulletin 257, April 1981. "When Darwin was bombed we were told [officially] that there was a raid on Darwin and nine people had been killed and several injured...[however] the bush telegraph told us that 150 people had been killed. By the time the ship arrived in Cairns with shrapnel rows all up and down her side, and loaded to the plimsoll with casualties, we knew they had had it." Brody, op.cit.

21 G.L. Broughton, op.cit. There was also an airlift from New Guinea, George Broughton recalled: "One plane crashed in the mangroves not far from the airport. Other New Guinea people came down to Cairns in craft of all shapes and sizes under great difficulties. One man 
told me he did not have navigational instruments to $\mathrm{d}[\mathrm{e}]$ termine his longitude but could work out his latitude, so he came south until he was in latitude 14 degrees and then steered due west and came through the Cook opening until he struck the mainland." p.3.

$\underline{22}$ "Of the 1400 service personnel at Rabaul in January 1942, only 400 managed to escape", or 28.5\%.Bradley, op.cit., 1995, p.43.

$\underline{23}$ "The immensity of the Japanese threat which faced North Queensland after the enemy's conquest of Java early in 1942 is indicated by the fact that a Dutch convoy, fleeing from the Netherlands East Indies [which became Indonesia in November 1949], steamed down the Gulf of Carpentaria and reached Karumba at the mouth of the Norman river without the V[oluntary] D[efence] C[orp] Unit, which was the sole defender of that area, being aware of its coming." This highlighted the fact that if the Dutch could do it, so too could the Japanese. Sunday Australian [Cairns], 9 September 1945, p.16.

${ }_{24}$ Mehlert, "Looking Back: Looking Ahead 1942-1992", HSC, Bulletin 379, May 1991.

${ }_{25}$ Although less than half had returned by June. D. Day, Reluctant Nation, OUP, South Melbourne, 1992, p.3.

26 MacArthur arrived in Melbourne on 17 March 1942. J. Beaumont, (ed) Australia's WAR 1939-40, Allen \& Unwin, St. Leonards, 1996, p.xvi.. South West Pacific Area (SWPA). p.xvi.

27 Bolton's figures correlate with the George Groom, founder and editor of the Sunday Australian [Cairns], 9 September 1945, p.6, where he identifies that "Within Cairns itself, the number of electricity disconnections, between January 29 and March 16, 1942, after allowing for reconnections, totalled 645. Throughout the area controlled by the Barron Falls HydroElectricity Board, which extends as far south as Babinda, total disconnections were 964." Allowing for $4 \frac{1}{2}$ persons per dwelling (a council accepted average) Groom correctly calculates that 2,902 residents of Cairns city disconnected their electricity, however, he also observed that "there were numerous instances in which families who went south in the great evacuation trek did not have their power lines disconnected." Groom concludes that 'Cairns lost between 5000 and 6000' residents. Sunday Australian [Cairns], 9 September 1945, p.6. 
${ }_{28}$ G.C. Bolton, A Thousand Miles Away, ANUP. Canberra, 1972, p.336. "Other women [in the far North] adopted the procedure of burying their valuables in the ground near their homes." Sunday Australian [Cairns], 9 September 1945, p.6.

$\underline{29}$ For an overview of internment, see K. Darian-Smith, "War and Australian Society" in Beaumont, op.cit., pp.55-59.

30 Cairns Post, 30 January 1942.; North Queensland Register, 7 February 1942, gives a total of 800 having left, cited in Saunders \& Taylor, "The Impact of Total War Upon Policing: The Queensland Experience", op.cit., p.148 (n.23); "The editor of the Cairns Post later recalled that: '...The police made a canvas of the area and told the women they were not compelled to leave yet; but it would be advisable for them to go. As, if they left when first warned they would be able to go where they wished, but if they waited for an official order (which the police believed might come any day) they would have to go where they were sent and there would be all sorts of difficulties.' "

31 It gave a leg-up in the tough economic climes for some hardworking and enterprising locals. One of whom was Horrie Kennedy, who completed his electrical apprenticeship in 1929, and when he could not gain employment, he borrowed $£ 50$ from his dad, bought a bicycle and began his own electrical contracting business. He gained work and bought 'City Electric Light' (25 Aplin St.) from Frank Blutcher (his former employer). By 1941, Kennedy as an electrician, was classified as being in an essential industry, and was required to remain at his job in Cairns. When Cairns was evacuating, and land prices slumped, and with his limited capital Kennedy was able to purchase and move his "business to the corner of Aplin and Abbott Streets, later becoming known as Kennedy's corner, opposite the council chambers [which have since been transformed into the new Cairns City Library]." H.R. Kennedy shared the building with the army during the war, but in 1946 lost the building to a fire, but battled back and 'was involved in electrical installation all over the Far North and beyond.' Cairns Sun, 17 January 2001, p.13.

32 Mrs E. Doherty (née MacKenzie) quoted in V. Brown, "Cairns At War", HSC, Bulletin 349, August 1989. 
$\underline{34}$ By 1942, one camp down South, "held at least 4,000 or 5,000 Japanese from all around the country. From Indonesia, from Taiwan, New Caledonia, from all around Australia - Broome, Darwin, Cairns." Jack Takagaki whose father arrived in Mackay in 1901, and was 11 yearsold when on Monday 8 December 1942, the police came and picked up his family (his sister and two brothers and father; his Western mother had died just before the war). D. Neville (ed), Sweet Talking: A collection of oral histories from the Australian sugar industry, Australian Sugar Industry Museum, Mourilyan, 1998, pp.22-28.

35 Cairns Post, 10 December 1941. In Queensland, within 3 days of Pearl Harbor, 1,470 Japanese were interned (p.13). Maud Kehoe (née Williams) whose family owned the Lake Eacham Hotel recalled "our hotel was a popular retreat for people living on the coast to escape the heat, so we were kept extremely busy, and like many other hotels in North Queensland employed Japanese staff. Harry Iashi and Peter were cooks, Toby and another chap did the laundry while Tommy Oda was the gardener...These men were with us for years and had their quarters in the hotel garden, [and] often had their Japanese friends from Hides Hotel in Cairns stay with them...the day Japan bombed Pearl Harbour [sic]...The authorities had come in, rounded them all up, not even giving them time to take off their cook's apron before escorting them away to an internment camp." [V. Bradley, I didn't know that Boolarong Press, Moorooka, 1995, p.307.] It would appear that one of these men actually escaped the authorities and an alert was issued to the Top Gate on the Gillies Highway, where "a man of Asiatic features, who appeared to be hiding behind a newspaper", was observed in a bus. A message via carrier pigeon was sent to Cairns where, when the bus arrived, the Japanese passenger was arrested. T. \& E. Tranter, A Bend Too Many - The Story of the Gillies Highway, Eacham Historical Society (EHS), Malanda, 1999, p.26.

${ }_{36}$ Cairns police report on internment of Japanese, 15 December 1941 [QSA Police department file A/12001], cited in K. Saunders, War on the Homefront, State intervention in Queensland 1938 - 1948, UQP, St. Lucia, 1993, p.45, n.36.

$\underline{37}$ K. Saunders, "Enemies of the Empire? The Internment of Germans in Queensland During World War II", in M. Jurgensen\& A. Corkhill (eds), The German Presence in Queensland,, Department of German, UQ, Brisbane, 1987, p.56. Clive Morton makes the salient point that "unlike Italians who had fought on the Allied side in the first World War in the Italian Army, hundreds of young men of German descent had fought in the same war as Australians. Names of German origin on cenotaphs all over Australia prove this statement." A local cane-farmer, 
Martin Drexl, having attended 2 lectures given by Von Luckner in 1937 was interned in 1939, which Morton considers was extremely unfair considering the sycophantic attendance of many civic dignitaries who were still classified as patriotic. Morton, By Strong Arms, 1995, p.131.

$\underline{38}$ In June of 1939 "the Commonwealth Government passed an Act relating to the Registration of Aliens compelling the registration of foreign nationals. Many of the North Queensland Italians were unnaturalized." D. Menghetti, " 'Their Country, Not Mine': The Internments", in B.J. Dalton (ed), Lectures in North Queensland History No.4, History Department, JCU, Townsville, 1984, p.195.

39 R. Fitzgerald,A History of Queensland, From 1915 to the 1980s, UQP, St. Lucia,1985, p.112..

${ }_{40}$ Aliens (Italian, Yugoslavs, Albanian, Greeks and others) registered at the Cairns Court House after 'filing into Cairns from rural areas' once the announcement of war with Germany and the Alien registration requirements were issued. The Sunday Australian [(Cairns), 9 September 1945, p.4] reported that police officers, "yesterday saw a constant stream of residents of twenty nationalities report at the court house for finger printing and the submission of photographs and details." Failure to comply meant a $£ 100$ fine or six months in prison.

${ }_{41}$ Similarly, rural life was impeded by the ban on having a wireless receiver, electric torches, motor vehicles, boats and fuel. Menghetti, op,cit., p.197; Beaumont, op.cit., p.56. There was for all intents and purposes, at least one exception in the district. Hungarian-born Dr Ian Brody who arrived in Gordonvale in 1941 and took over the running of the only medical practice in the town. His position had many other roles attached including being the armed forces medical officer. Not surprisingly his work was classified as essential, but that did not stop the local police sergeant. Upon Germany dragging Hungary into the war on the side of the Axis powers, Ian Brody overnight became an 'enemy alien'. He was required to obey a curfew, except if he had to attend to some-one who was sick. The Sergeant serched the doctor's house and proscribed that Brody was not allowed to have a radio, but when told it belonged to Mrs Brody, an Australian, that was alright. [Interview with Dr J. Brody, COHP, Tape 0397, 1A, 12 December 1997.] In the case of Dr Brody, who had been forced to leave 
Europe because of the Nazis' expansion, his 'enemy alien' status seems to have been rapidly forgotten in lieu of his pivotal medical role for the Mulgrave district.

42 Inspector P.J. Honan of the Cairns police, advised "against approval of the purchase of a Mareeba tobacco farm by a naturalized citizen, noted that local feeling was hostile to further land acquisitions by Italians."[Menghetti, " 'Their Country, Not Mine': The Internments", 1984, op.cit.]One cannot help but agree with the observation that: "Specific complaints lodged by Anglo-Australians tell us more about the prejudice of the complainant than about the subversive activities of this section of the population." Saunders \& Taylor, "The Impact of Total War Upon Policing: The Queensland Experience", op.cit., p.150.

${ }_{43}$ Returned Sailors \& Soldiers Imperial League of Australia : From Sydney to Townsville, Ayr and Cairns, the organisations' branches passed resolutions calling for the immediate internment of all enemy aliens. To the south of Cairns, in the Hinchinbrook Shire alone, some 147 cane farmers and 386 cane-cutters and field hands were interned.Menghetti, " 'Their Country, Not Mine': The Internments", 1984, op.cit., p.205.

${ }_{44}$ Menghetti identifies that "Families left without means were given subsistence government pensions." One mother "received nine shillings a week for herself and her two babies, dropping to $8 / 9$ when it was discovered that she was being given milk from a neighbour's cow." op.cit., pp.204-205.

45 Internment was carried out by the local Queensland Police,and their"enthusiasm for containing both radicals and ethnic minorities reflected and endorsed prevalent community xenophobia and antagonism towards these outsiders. Commonwealth regulations [under the National Security Act of 1940], produced in response to the national crisis of war, gave the police the ideal pretext and legitimacy to harass those groups they had long deemed dangerous to the well-being of the community." Saunders \& Taylor, "The Impact of Total War Upon Policing: The Queensland Experience", op.cit., pp.163-64.

${ }_{46}$ R. Fitzgerald, A History of Queensland - From 1915 to the 1980s,UQP, St. Lucia, 1985, p.113.

${ }_{47}$ The District Inspector of Schools, H.G. Watkins, identified that of the usual 2,800 children, some 2,200 had left between December 1941 and March 1942. Sunday Australian, Cairns, 9 September, 1945, p.6. Gordonvale's only medico, Dr Ian Brody, recalled "I had very little 
work to do because all the women and children were evacuated. The police went from house to house, and said 'you have to be evacuated. And if you don't go you will be forcibly evacuated, and you will be housed under canvas west of Charleville, which was a complete fabrication...some people in Quilpie evacuated to a place five miles from Quilpie, as long as you evacuated that was the important thing...It is what you would call war hysteraia."Interview with Dr J. Brody, COHP, Tape 0397, 1A, 12 December 1997.

${ }_{48}$ C. deG. Williams, [Town Clerk, Cairns City Council],"Cairns Population, Year Ending 30 ${ }^{\text {th }}$ June, 1891-1958",HSC, c.1959, D2200, also D3985.

49 Margaret MacLean recollections in V. Bradley (ed), I didn't know that, 1995, p.192. The paratroopers comprised the US 503-501 Parachute Infantry Regiment \& 'A' Company 504 Parachute Infantry.

${ }_{50}$ Turn-over in the motor trade had in a matter of months dropped by more than half; and at the Cairns Wharves, the once formidable 400 strong labour force, fell to about 180.Sugar producers were suffering and "there was a wild rush to convert paper currency into silver, which prospective refugees considered, would be the only tender that would be negotiable in any evacuation." Sunday Australian [Cairns], 9 September 1945, p.6.

$\underline{51}$ The subject of the 'scorched earth' policy was secret, as the authorities wanted to deny any Japanese invasion force of the amenities or transport links of the district, as well as not wanting to exacerbate civilian fears.

52 Included in the 'scorched earth' policy were the Bunda Street Gas Works, the oil tanks, wharves and water supply. The Barron Falls Hydro-Electricity Board and the Railway apparently organised this aspect themselves.

${ }_{53}$ Personal communication with Vera Bradley, also V. Bradley, I didn't know that, Boolarong Press, Moorooka, 1995, pp.55-56. D. Jones, Trinity Phoenix, 1976, p.468.

54 See "Impressment", Bradley, op.cit., pp.75-77. "Because of his local knowledge, Bill Headrick a Cairns produce agent, was seconded from the AIF, given the assistance of an American army officer and sent out to seize tractors and arrange compensation. A lorry from local carrier and Vacuum agent Bert Thomas, driven by Bill Heaslop loaded tractors at roadside cuttings and the occasional ramp." Morton, By Strong Arms, 1995, p.132. 
${ }_{55}$ P.D. Wilson, North Queensland WWII 1942-1945, Department of Geographic Information, Brisbane, 1988, p.28.

56 "The Queensland government, espousing a parochial commitment to the supremacy of State sovereignty and autonomy, did not easily relinquish its own powers and was often in conflict with both the Menzies and Curtin federal governments." K. Saunders, War on the Homefront, UQP, St. Lucia, 1993, p.145.

${ }_{57}$ R. Fitzgerald,A History of Queensland - From 1915 to the 1980s,UQP, St. Lucia, 1985, p.102-03;"There was no such plan...If there were, it would appear strange that the Federal Government was spending money on road construction in North Queensland before the outbreak of the Pacific War, as well as improving airfield facilities in North Queensland." [P.D. Wilson, North Queensland WWII 1942-1945, 1988, p.11.] The Brisbane Line "remained a potent symbol in folklore in Queensland and Western Australia. Most Australians convinced themselves that for the only time in modern history their country had been in danger. This sense of peril encountered and resisted helped to shape much of the thinking about the future."G. Bolton, The Oxford History of Australia 1942-1988 'The Middle Way', Vol. 5, OUP, Melbourne, 1990, p.15

$\underline{58}$ "A statement by the American general, Douglas MacArthur, reported in the Brisbane Telegraph, Sydney's Daily Telegraph and the Melbourne Argus of March 1943, but pointedly ignored by the conservative Courier Mail, added fuel to the controversy. (A year after his arrival in Australia MacArthur inadvertently spoke of previous plans to defend Australia on the mainland rather than in New Guinea,stating that it was the intention of Australia in March 1942 to defend along a line somewhere near the Tropic of Capricorn, which would be known as the 'Brisbane Line'. The role of Port Moresby was to hold the enemy, to enable mainland defences to be brought into action.)"Although, it still was not true.Bolton, ibid.

59 "An Australian Army Engineer unit set up camp on the Little Mulgrave River during early 1942 and worked for sometime installing sufficient explosive devices at strategic spots on the Gillies Highway to destroy the road if the need should have arisen. It is believed that the road was mined in three places, and as well, explosive devices were installed above the road, which if detonated would have caused massive landslides." T. \& E. Tranter, A Bend Too Many - The Story of the Gillies Highway, Eacham Historical Society, Malanda, 1999, p.25. 
60 Wilson, North Queensland WWII 1942-1945, p.18. The airfield was intended for use by USAAF B-17 Flying Fortresses, but the first unit to occupy it was 100 RAAF Squadron, equipped with Beaufort torpedo bombers, which transferred to Port Moresby after a brief training period." The Queensland Main Roads Commission who had been requested to build the airstrip, had to bring its plant from Herberton, but nevertheless, completed the $7,400 \mathrm{ft}$. $(2,200 \mathrm{~m})$ by $200 \mathrm{ft}$. $(60 \mathrm{~m})$ on time; "A second strip was then laid down of similar length and width, with a seal coated taxiway between the two." A major problem was trying to settle the dust with affected both flying and constructional operations, which was "overcome by spraying with a mixture of one part molasses to four of water." Approximately $£ 353,000$ was spent on Mareeba airport during the war, and the project employed 700 men. History of the Queensland Main Roads Commission during World War II 1939-1945, A.H. Tucker Government Printer, Brisbane, 1949, p.23.

61 G.P. "Some Wartime Memories Mareeba 1942-43", Northern Sun, Vol. 8, No.26, November/December 1993, p.5.

62 V. Bradley, I didn't know that, 1995, p.63. "The Japanese had postponed plans for further offensives, except those that secured their hastily won empire. Mounting a scaled-down offensive to cut Australia's lifeline to America remained a top priority for Tokyo. Although Australia was secure from invasion in the medium term, her links to America were of the most vital importance. If they could be cut, Australia would again be vulnerable to conquest. And if Port Moresby fell, a door into northern Australia would be forced wide open." D. Day, Reluctant Nation: Australia and the allied defeat of Japan 1942-45, OUP, Melbourne, 1992, p.45.

63 Wilson, op.cit., "The clash resulted from Japanese plans to capture Port Moresby by seaborne assault, in order to secure air superiority over North Queensland and the Coral Sea. This air superiority would, in turn, have guarded the right flank of the planned Japanese advance south-eastwards towards New Caledonia and Fiji, with the objective of cutting sea and air communications between Australia and the United States."p.36.

64 The atoll was so-named because it is mid-way across the Pacific Ocean. J. Bryan III, "Midway: Turning-Point in the Pacific", in Reader's Digest Illustrated Story of World War II, Sydney, First Edition, 1970, pp.286-303. 
65 ibid., pp.314-325. "The speed of their advance took Japanese planners by surprise. For some weeks their army and navy leaders debated as to whether they should invade the north of Australia. By 7 March the army's view against this had prevailed, and the Japanese agreed instead to isolate Australia by seizing Fiji, Port Moresby, New Caledonia and the southern Solomons. Australia would thereby be neutralised as a potential base for a US counteroffensive..." J. Beaumont, Australia's War 1939-45, Allen \& Unwin, St. Leonards, 1996, p.30.

${ }_{66}$ The rugged jungle-clad mountain terrain along with the glutinously muddy tracks made it extremely difficult to traverse, particularly as the Japanese had such extended supply lines. "Although the situation was certainly critical, every retreat by the Australians lengthened the lines of communication for the Japanese and reduced their advantage." Day, Reluctant Nation, 1992, p.44.

67 "[T]he climatic battle never came. Instead, Tokyo ordered the Japanese to relinquish their hard-won gains and retreat northwards to the coast. They had failed to occupy the airfield at Milne Bay and were encountering unexpectedly stiff opposition from the Americans at Guadalcanal. Suddenly, Moresby became one commitment too many for the overstretched Japanese. Just when victory was so close they could taste it, it was whipped away." ibid., p.55.

${ }_{68}$ Major-General Sydney Rowell was relieved of his command of the Australian New Guinea Forces by General Blamey in late1942. Vasey was his replacement. For a balanced coverage of the circumstance of Rowell's sacking, see J. Beaumont, op.cit., p.39.

69 J. Morrison, "The Kokoda Track", Australian, A Special 50 ${ }^{\text {th }}$ Anniversary Publication, 1995.

70 For a comprehensive coverage, see V. Bradley, I didn't know that. Cairns and Districts Tully to Cape York, 1939-1946, Service Personnel and Civilians,Boolarong Press, Moorooka, 1995.

${ }_{71}$ Ex-Sgt. Alex Briggs recollections in ibid., p.178.

72 Esplanade Memorial Plaque in honour of the Catalina crews, quoted in A. Broughton, "Catalina A24-35", HSC, Bulletin 268, April 1982. 
73 The U.S. 1st Marine Division landed on the 7 August 1942 and the islands and the renamed Henderson Field' were captured within 3 days. "Determined to regain the airfield, the Japanese struck back by land, sea and air. Reinforcements were rushed from their base at Rabaul. Night after night, Japanese warships bombarded the land positions...In the Battle of Savo Island (August 9), four Allied heavy cruisers were sunk and a fifth crippled. Several more engagements were fought...In the Battle of the Santa Cruz Islands (October 25) the carrier Hornet was sunk and the Enterprise disabled. The tables were turned in the naval battle of Guadalcanal (November 13-15) when 11 Japanese troop transports, 2 battleships, 1 cruiser and 3 destroyers were sunk." [C. Bateson, "Guadalcanal: First Stop on the Road to Tokyo", in Reader's Digest Illustrated Story of World War II, Sydney, First Edition, 1970, p.306.] Land assaults by the Japanese continued and the Americans were re-enforced, first by the $7^{\text {th }}$ Marine regiment, followed by the U.S. Army Americal Division, which brought final success on 7 February 1943.

74 ibid., pp.304 - 313. Australian forces comprised "The Infantry Battalions of the $7^{\text {th }}$ Brigade moved to Milne Bay from Townsville in July 1942 (9, 25, 61 Battalions - all Queensland raised units). There, in August, with $18^{\text {th }}$ Brigade of Seventh Division A.I.F. (2/9, 2/10/ and 2/12 Battalions) which arrived direct from Brisbane," It was these troops who repelled the Japanese invasion force. Wilson, North Queensland WWII 1942-1945, 1988, p.12.

75 Japanese casualties amounted to about 1,000 men (700 of the landing force and 300 drowned when the Nankai Maru was sunk). "The Milne Bay operations were important in their results. Strategically they confined the main Japanese operations in Papua to the BunaKokoda area and spelt failure for the Japanese plans to capture Port Moresby. This first land victory over the Japanese since December 1941 had a tonic effect not only for the Australians, but much farther afield." The Australians lost 161 men with 373 casualties. D. McCarthy, "Victory at Milne Bay", in Reader's Digest Illustrated Story of World War II, Sydney, First Edition, 1970, p.201.

${ }_{76}$ N. Stubbersfield, "Communications during World War II: A Personal Reminiscence", in Journal of the Royal Historical Society of Queensland (JRHSQ), Vol.16, No.6, May 1997, p.274-75.

${ }_{77}$ Historyof the Queensland Main Roads Commission during World War II 1939-1945, A.H. Tucker Government Printer, Brisbane, 1949, p.28. 
$\underline{78}$ "[E]very empty shop, house, business premise or workshop left vacant by the evacuation was taken over..." ibid., p.63. Housing was acquired either by official requisition or by private contract. M. Eastgate, "Brigadier North and the Defence of North Queensland", in JRHSQ, Vol. XV, No.2, May 1993, p.86.

79 Sunday Australian [Cairns], 9 September 1945, p.11. Townsville's population had swelled from 28,000 to 100,000 and American troops particularly liked their milk. Subsequently, the Malanda Butter Factory was to supply 38,000 litres (10,000 gallons) of milk every day, by trucking down the Palmerston Highway to Innisfail, then by train to Townsville. M. Eastgate, "Brigadier North and the Defence of North Queensland", in JRHSQ, Vol. XV, No.2, May 1993, p.86.

80 State-wide 3,500 Indigenous Queenslanders were 'employed in jobs that Europeans normally occupied.' L. Hume, "Them Days: Life on an Aboriginal reserve 1892-1960", in Aboriginal History, Vol. 15, No.1-2, 1991, p.19. See also T. Bottoms, Djabugay Country, Allen \& Unwin, St. Leonards, 1999, p.66.

81 "At its peak the AWLA [Australian Womens Land Army] force in Australia totaled 3,500 girls, of which 700 would have been permanent, plus seasonal girls in Queensland. When WWII ended, the members quickly returned to civilian life and the AWLA was officially disbanded in December 1945." Bradley, op.cit., p.320. See also, E. Mazlin, "Experiences of a Land Army Girl in North Queensland", HSC, Bulletin 381, July 1992.

82 Queensland Parliamentary Papers, 1943, p.685.

83 Bradley, op.cit., p.190. One of the parachute packers, Margaret MacLean, remembered: "We were paid $£ 5$ per week, which was a lot of money for a female, 'it was more than my father was paid'. One thing we were thrilled about was the 10-minute break allowed every hour, something unheard of in Australian working conditions. We were the envy of a lot of other working girls, who thought our pay and conditions were good, but did not realize the pressure we worked under and how hard it was on us. We normally worked 8 am-5 pm, but when the men were training work could go on well into the night or early morning six days a week with no extra pay." p.192. 
84 Colonel Kenneth Kinsler. ibid., p.190. Kinsler and 15 of his officers, in order to engender confidence in the quality of the local parachute packing, made the first jump at Gordonvale on 29 December 1942. (p.192)

85 Their camp-site was on Riverstone Road between Hemming and Alley Creeks.

${ }_{86}$ Bradley, op.cit., p.191. One US Paratrooper, Frank Deal, remembered one practice session where they:"jumped from C-47's at Green Hill, [and] the roadway was filled with paratroopers, 'chutes and equipment of all sorts. An old cranky farmer came fuming down the road trying to weave his way through the crowd on his bike, yelling: 'Get off the bloody road. The war's not here, its up in bloody New Guinea ! - Off the bloody road !!!' " Cited in W. Bossert, "Coming Back", Mulgrave Shire Historical Society, Bulletin 236, March 2001.

87 Bradley, op.cit., pp.193-94.

88 'H' Australian Heavy Battery, 127 man unit . S. Fowler, "False Cape At War", HSC, Bulletin 444, March 1998.

${ }_{89}$ Formerly known as 'Leper Bay', in 1932, Mr and Mrs C. Kielsen, the only residents living there, changed the name to 'Sunny' Bay.Northern Affairs, 8 January, 1932, p.5.

90 It was to take another 30 years before a road was built to Bessie Point and Yarrabah (1972).

91 Around the corner at Fitzroy Island, the Cairns Harbour Board had organised the construction of facilities for the RAAF who established a 40-man Radar Station (No.28). Their responsibility was to monitor and "identify all ships, submarines and planes, and immediately notify any unauthorised sightings to RAN Fairmile anchored in the lee of the island for investigation." J. Davidson, (Officer in Charge of Fitzroy Island Radar Station, March 1943), recollections in Bradley, op.cit., p.223.

92 "Figures compiled by the Center of Military History in Washington [DC] show that in December 1943 there were 307141 Americans in Australia and New Guinea, rising to a peak of 506702 in May 1944, and dropping slightly in June 1944." [E.D. \& A. Potts, Yanks Down Under 1941-45, OUP, Melbourne, 1985, p.29.] By September 1943, 81\% of the 110,000 American forces in Australia were located in Queensland, that is 96,000 personnel. K. 
Darian-Smith, "War and Australian Society", in J. Beaumont (ed), Australia's WAR 1939-40, Allen \& Unwin, St. Leonards, 1996, p.72.

93 Bradley, op.cit., p.210 A private contractor with members of the Allied Works Council (AWC) got to work converting a mill building in Kenny Street as a mess hall, as well as construction of another 57 barrack buildings along Dutton and Hartley Streets. Other facilities for the US Army were under construction west of the Cook Highway at Trinity Beach, but had to be finished by Company B of the US 532 Engineer Special Brigade (ESB).

94 H.G. Conner, recollections in Bradley op.cit., p.213. One of the units involved in the landing excercises was the $1^{\text {st }}$ Australian Landing Craft Workshop AEME (Australian Electrical \& Mechanical Engineers), who formed the Australian Army Water Transport Craft RAE (Royal Australian Engineers). Upon their arrival in early 1944, they set up camps near Yorkey's Knob and Machans Beach. They operated slower Australian-built landing craft, constructed by Evans Deakin Shipyards, Kangaroo Point, Brisbane. P. Goldston, "Wartime Memories of Cairns", HSC, Bulletin 380, June 1992.

95 Washington Daily News, March 1945, and H.G. Conner's recollections in Bradley, op.cit.,, pp.212-13. "Timber for the construction of barges was supplied by the Cairns Timber Mill Pty Ltd in Spence Street, motors and other material being shipped in from America." p.211.

96 Their elusiveness meant that they were not scientifically identified until 1956, as a new species, Chinorex fleckeri, named after Dr Hugo Flecker. Discovered by marine expert, Dr. Jack Barnes who named it after his friend Flecker. J.R. Clarkson, "Dr. Hugo Flecker", HSC, Bulletin 384, October 1992; Cairns Post, 27 February 1988, p.23. The Airport Mangrove walk was named in honour of Jack Barnes and his pioneering work.

${ }_{97}$ Wilson, North Queensland WWII 1942-1945, 1988, p.9. The hospital ship Centaur had 268 lives lost or $42 \%$ of the overall loss of life from Japanese submarine attacks in Australian waters. It was generally considered a barbarous act that confirmed Japanese callousness, for the ship was sunk 'despite the fact that it was a convention of war not to attack hospital ships and the Centaur was clearly marked with red crosses.'G. Aplin, S.G. Foster, \& M. McKernan (eds), Australians - Events and Places,Fairfax, Syme \& Weldon Associates, Broadway, 1987, p.159.

${ }_{98}$ A. Amos recollections in Bradley, op.cit.,p.167. 
99 ibid., p.169. The old Japanese fishing boat the Kofuku Maru had been brought to Sydney and renamed the Krait, after a venomous snake of India.A six-cylinder diesel engine was located in Tasmania and sent north to be installed, while intensive training for the crew continued in the scrub around Fairview. In August 1943 and the Krait and her crew departed Cairns for Exmouth.Not all missions were successful. The next one, 'Operation Rimau', left by submarine from northern Western Australia in 1944. Tragically for the raiders it failed, with 13 commando's killed in evasive action and 10 captured and beheaded. Jones, Trinity Phoenix, 1976, p.471.

100 A. Amos recollections in Bradley, op.cit., p.166.

${ }_{101}$ Bottoms, 1999, op.cit., p.67. The majority were men from Java, and their camp was located in what is now the Cairns suburb of Bungalow [Between Scott and Severin Streets]. They were being trained to infiltrate behind enemy lines, and the "Training went on day and night at the beaches and on the sea around Cairns. For special exercises they were taken to a secret training area behind Hartley's Creek, on the Cook Highway." [Lieut.Fred Uyterwijk in Bradley, I didn't know that, pp.374-5].Many times they were secretly dropped off'back of Redlynch', and were required to find their way back to camp undetected [Pers.com. V. Bradley, Cairns, 14 August 95]. It therefore seems quite likely that it was these Javanese, who were sprung by the Mission Aborigines on one of their secret patrols!

102 Wilson, op.cit., p.35.

103 Australian militia (iitizen Military Forces) could only be employed within the boundaries of Australia and her territories (including PNG). A simmering issue came to the boil with the existence of two Australian armies, the AIF and the CMF. In October 1942 the CMF numbered 262,333 men which was more than the 171,246 men in the AIF. The veteran regulars of the AIF considered the CMF 'chocolate soldiers' or 'koalas' (a species that could not be shot at, nor exported !). Nevertheless, the demarcation of where they could fight, was also a bone of contention with the American forces, who felt that if they could be conscripted to fight for the defence of Australia, why could the CMF not also be sent overseas. J. Beaumont, Australia's WAR 1939-40, Allen \& Unwin, St. Leonards, 1996, p.41.

104 "In that month 30,600 military personnel, 37,000 civilians, 55,000 tons of military loading and 70,500 tons of civilian loading had been conveyed north of Brisbane." A. Whiting, 
"Differences in Queensland Military Rail Transport," JRHSQ, Vol. XV, No.2, May 1993, p.97.

105 Sunday Australian [Cairns], 9 September 1945, p.11. Maureen Frazer, who was assistant gate-keeper on the Gillies Highway during this period, remembered: "on one day a convoy of 640 Australian Army vehicles checked through the top gate. The regular opening and closing times for the gates were abandoned while this huge convoy had absolute priority." T. \& E. Tranter, A Bend Too Many - The Story of the Gillies Highway, Eacham Historical Society (EHS), Malanda, 1999, p.26

${ }_{106}$ P.D. Wilson, North Queensland WWII 1942-1945, Queensland Department of Geographic Information, Brisbane, 1988, map.

107 ibid., p.6.

108 "[A]n estimated 10 per cent of Japanese troops in New Guinea had died from Malaria..." Cairns Post, 22 September 1972, p.2.

109 The ratio of medical to battle casualties in the 1942 Australian Papuan campaign was almost 8:1. Wilson, op.cit., p.13.

110 M. Spencer, Malaria The Australian Experience 1843-1991, ACTM Publication, Townsville, 1994, p.48.

111 Brigadier (Sir) Neil Hamilton Fairley and Lt.-Col. Ian Mackerras (both medico's) were sent to Port Morseby to report on conditions in Papua-New Guinea. Cairns Post, 22 September 1972, p.2. See also Spencer, ibid., pp.51-53.

112 Spencer, ibid., p. 51.

113 75 ${ }^{\text {th }}$ Anniversary 1876-1951 Cairns, "Queen City of the North": Jubilee Year Souvenir, Hartshorne-Waller Publicity for the Jubilee Celebrations Committee, Townsville, 1951, p.9. The main drain was laid down Spence Street and "covered two-thirds of the watershed on the southern side of the city, and also the Bungalow area, which was a veritable reservoir of malarial infection." D.V.J. Glasgow, Senior Health Inspector, Cairns City Council, "Malaria Eradication in Cairns Under Civil Control" in Report of the Twelfth Annual Conference (of 
Health Inspectors) held at City Council Chambers, Health Inspectors Association of Australia, Queensland Branch, 26-29 June 1950, p.31.

114 In the same period Cairns City had approximately half the districts cases with 1000 patients. [Mayor W.H. Murchison, "Official Opening (26 June, 1950), ibid., p.3.]75 ${ }^{\text {th }}$ Anniversary 1876-1951 Cairns, "Queen City of the North", Jubilee Year Souvenir, Hartshorne-Waller Publicity for the Jubilee Celebrations Committee, Townsville, 1951, p.9.

115 In 1950, Cairns had not experienced any cases of malaria for two years (i.e. since 1948). W.H. Murchison (Mayor of Cairns), in Report of the Twelfth Annual Conference (of Health Inspectors) held at City Council Chambers, Health Inspectors Association of Australia, Queensland Branch, 26-29 June 1950, p.6.

116 Bradley, op.cit., p.256.

$\underline{117}$ K. Darian-Smith, "War and Australian Society", in Beaumont, op.cit., p.63. "In the 1940s paid employment of married women was generally considered socially unacceptable, at least among the middle class, and especially when there were young children in the family. War bestowed a temporary legitimacy of the employment of wives and mothers outside the home by stressing it was not economic necessity, but patriotic duty, that pushed married women into the workforce."p.66.

$\underline{118}$ From 644,000 in 1939 to 855,000 in 1944.Beaumont, ibid., p.65.

119 G. Bolton, The Oxford History of Australia - The Middle Way 1942-1988, Vol. 5, OUP, Melbourne, 1990, p.17.

120 As well as competing in jive and jitterbug competitions. V. Bradley, op.cit., p.121. Miss Downey observed of the time that: "Nothing was forgotten by these men. They even sent courtesy cars to take the girls to and from the dances, and they held parties for children at the American Red Cross Service Club."

121 "By June 1943, 90 per cent of Australian men and 30 per cent of women were in either the armed forces, essential civilian jobs or direct war working..." G. Bolton, The Oxford History of Australia 1942-1988 'The Middle Way', Vol.5, OUP, Melbourne, 1990, p.14.

$\underline{122}$ Bradley, op.cit., p.232. 
$\underline{123}$ Bolton, , op.cit., 1990, p.21.

124 N.L. McKellar, From Derby to Burketown, The A.U.S.N. Story, UQP, St. Lucia, 1977, p.484.

125 H. Speight recollections in Bradley, op.cit., 1995, p.386.

126 ibid.

127 M. Herron recollections in Bradley, ibid.

$\underline{128}$ Three women were murdered in Melbourne and a US private, Eddie Leonski, was arrested , found guilty and hanged. It was at MacArthur's insistence that Leonski 'be tried with haste...[and] was intended to curb anti-American sentiment.' K. Darian-Smith, "War and Australian Society", in Beaumont, op.cit., p.75.

E.D. \& A. Potts, Yanks Down Under, pp.234-35; K. Saunders, "Reassessing the Significance of the Battle of Brisbane" in JRHSQ, Vol. XV, No.2, May 1993, pp.70-73, see endnote 5 .

130 United States Military Police or "Provosts were particularly disliked by Australians for their use of batons and weapons on American servicemen." Fitzgerald, A History of Queensland from 1915 to the 1980s, p.109.

131 "In mid April 1942 Colonel C.H. Barnes Jr wrote a crucial report to the Commanding General United States Forces in Australia on the subject of 'racial clashes between American negro troops and American white troops in Brisbane, Queensland, Australia'. He detailed a series of serious riots which had occurred from 11 to 20 March when black troops attempted to enter 'dance halls and skating rinks patronized solely by white people'."Saunders, "Reassessing the Significance of the Battle of Brisbane" in JRHSQ, Vol. XV, No.2, May 1993, pp.71.

132 General MacArthur wrote to General Marshall in Washington: "I will do everything possible to prevent friction or resentment on the part of the Australian government and people with regard to coloured troops...their policy of 'White Australia' is universally accepted here...however, by utilizing these troops in the front zones away from the great centers of population...I can minimize the difficulties involved." MacArthur to Marshall 29 March 
1942, National Archives, Washington DC War Department. OPD Exec. 10 item 19D, cited in Saunders \& Taylor, "Management of Segregation", in Saunders, War on the Homefront, UQP,St. Lucia, 1993, p.67.

${ }_{133}$ Saunders, War on the Homefront, UQP, St. Lucia, 1993, p.75-76.

134 On 'Thanksgiving Day' on Thursday 26 November, after an American military policeman bashed a drunken GI, his Australian companions took exception, and before long Australian and American troops were fighting the provosts, then it turned into a major street brawl with several thousand involved, including civilians. One Australian private was shot dead and a dozen wounded by US military police. Saunders and Taylor note that: "Under these circumstances, where highly trained combat troops engaged in prolonged violent encounters with military police, and where Australian civilians were only too eager to join the fracas, the power of the civil police to maintain public order and safety was acutely tested and found inadequate." K. Saunders \& H. Taylor, "The Impact of Total War Upon Policing: The Queensland Experience", in M. Finnane (ed), Policing in Australia Historical Perspectives, NSWU Press, Kensington, 1987, p.156.

135 P. Merrotsy, "Bank Life in Cairns in the 1940's", HSC, Bulletin 448, July 1998. Personal communication with Peter Merrotsy 13 October 2001.

136 A very young Allied Works employee, Ray Brooks, on his first day in Cairns, got on the end of a queue for what he thought was for the picture theatre! R. Brooks recollections in Bradley, op.cit., p.305. Some Australian soldiers queued and then sold their position to an American for a $£ 1$, which then tripled the client's outlay as the visit cost 10/- for half an hour. Repeated several times, the 'queue-seller' stunt could prove profitable for those patient enough.

137 The Australian soldier-boyfriend of one of the Club's workers, who had been requested to work extra time, became impatient with waiting outside and tried to enter the 'American'sOnly' club. Due to previous contretemps, Allied soldiers were generally banned from one another's entertainment venues.

138 Ian Cox recollections in Bradley, op.cit., p.306.

${ }_{139}$ Clive Wise recollections in Bradley, op.cit., p.305. 
$\underline{140}$ Cairns Post, 16 August 1945, p.3.

141 "Special Souvenir Issue Commemorating North's Role in War", Sunday Australian [Cairns], 9 September 1945, p.12. "[F]ull control of the trans-shipment port by the Australians was not fully gained until March 10 1945, and it was not until early 1946 that the last of the Americans departed." Bradley also identifies that "up to June 1944 the estimated cost of the work carried out was US\$3,050,000." Bradley, op.cit., p.171.

$\underline{142}$ R.A. Hall, "War's End: How did the war affect Aborigines and Islanders?" in Queensland Review, Vol.3, No.1, April 1996, p.35.

143 ibid., p.396.

${ }_{144}$ D. Duffy, "Forty Years On", EHS, Bulletin 72, September 1981. 